\title{
STRUKTUR KOMUNITAS HUTAN MANGROVE DI PULAU SIBU KOTA TIDORE KEPULAUAN PROVINSI MALUKU UTARA
}

\author{
Abdurrachman Baksir ${ }^{1}$, Nebuchadnezzar Akbar ${ }^{1}$, Irmalita Tahir ${ }^{1}$, Irfan \\ Haji $^{2}$, Muhajirin Ahmad', Raismin Kotta ${ }^{2}$ \\ ${ }^{1}$ Program Studi IImu Kelautan, FPIK. Universitas Khairun Ternate \\ ${ }^{2}$ Lembaga IImu Pengetahuan, Ternate \\ Email : nezzarnebuchad@yahoo.co.id
}

Received Juni 2018, Accepted September 2018

\begin{abstract}
ABSTRAK
Ekosistem mangrove dijadikan sebagai tempat pemijahan, makanan dan pembesaran ikan, komunitas bentik. Ekosistem mangrove di pesisir pulau Sibu mendapatkan berbagai macam tekanan pemanfaatan dari manusia. Hal ini memberikan gambaran bahwa perlu danya informasi ekologi. Stasiun penelitian ditetapkan sebanyak 3 stasiun, yang meliputi bagian utara, selatan dan timur Pulau Sibu. Pengambilan contoh mangrove, di lakukan dengan menggunakan metode transect quadrant dan spot check. Hasil penelitian diperoleh ketebalan hutan mangrove dikawasan Pulau Sibu berdasarkan pengamatan adalah 410 meter (Stasiun I), 321 meter (Stasiun II) dan 389 meter (Stasiun III). Komposisi jenis hutan mangrove dari hasil pengamatan dan identifikasi diperoleh sebanyak 10 jenis dari 4 famili. Nilai struktur komunitas dan vegetasi mangrove berdasarkan stasiun pengamatan diperoleh $24,44 \mathrm{ind} / \mathrm{m}^{2}$ dan diikuti oleh stasiun II dengan nilai $24,17 \mathrm{ind} / \mathrm{m}^{2}$ dan terendah pada stasiun III yaitu 18,83 $\mathrm{ind} / \mathrm{m}^{2}$. Kategori peluang kehadiran jenis ditemukan paling tinggi terdapat pada stasiun I yakni $5,00 \mathrm{ind} / \mathrm{m}^{2}$, kemudian stasiun II dengan nilai 4,17 $\mathrm{ind} / \mathrm{m}^{2}$ dan stasiun III yakni $2,83 \mathrm{ind} / \mathrm{m}^{2}$. Persentasi tutupan tertinggi vegetasi mangrove ditemukan pada stasiun stasiun I yaitu 18,19, disusul stasiun II sebesar 15,29 dan terendah stasiun III dengan nilai 12,49. Kategori nilai penting untuk keseluruhan stasiun memiliki nilai sama yaitu $300 \%$. Struktur komunitas hutan mangrove di Pulau Sibu berdasarkan indeks ekologi (nilai kerapatan, frekuensi jenis, tutupan dan nilai penting) cukup baik, sedangkan keanekaragaman spesies masngrove termasuk dalam kategori sedang.
\end{abstract}

Kata kunci : Ekologi, Mangrove, Pulau Sibu, Spot Check, Transect Quadrant

\section{ABSTRACT}

The mangrove ecosystem in the coastal area as nursery, feeding and spawning ground fish and benthic communities. Mangrove ecosystems in 
the coastal Sibu Island found pressure of human utilization. This provides a desirable picture of ecological information. The research station is 3 stations, covering the north, south and east of Sibu Island. The line transects quadrant and spot check method was used in this study. The results showed that mangroves thickness between 410 meters (station I), 321 meters (station II) and 389 meters (station III). Mangrove composition found that 10 specieses belong to 4 families. The ecology index station I was $24,44 \mathrm{ind} / \mathrm{m}^{2}$, station II was $24,17 \mathrm{ind} / \mathrm{m}^{2}$ and station III was 18,83 ind $/ \mathrm{m}^{2}$. The frequency species was $5,00 \mathrm{ind} / \mathrm{m}^{2}$ (station I), 4,17 ind $/ \mathrm{m}^{2}$ (station II) and $2,83 \mathrm{ind} / \mathrm{m}^{2}$ (station III). The present cover mangroves ecosystem was 18,19 (station I), 15,29 (station II) and 12,49 (station III). While the important value at every station was 300 . Overall the condition of mangroves on the Sibu Island was in normal condition.

Keywords : Ecology, Mangroves, Sibu Island, Spot Check, Transect
Quadrant

\section{PENDAHULUAN}

Kota Tidore Kepulauan merupakan kabupaten/kota dengan potensi sumberdaya pesisir dan laut yang cukup baik. Pulau Sibu adalah salah satu pulau yang secara administrasi masuk dalam kecamatan Oba Utara, Kota Tidore Kepulauan. Pulau ini menyediakan tiga ekosistem pesisir dan laut yakni ekosistem mangrove, lamun dan terumbu karang. Ketersediaan ekosistem mangrove tentunya dapat mempengaruhi ketersediaan sumberdaya ikan, komunitas biota bentik dan menciptakan mata rantai didaerah sekitar. Secara umum diketahui bahwa fungsi utama ekosistem mangrove sebagai penyediaan bahan organik, tempat asuhan (nursery ground), tempat bertelur (spawning ground), dan tempat berlindung berbagai biota laut, serta sebagai pelindung pantai dari aktivitas gelombang (Saru, 2009).Selain itu hutan mangrove mempunyai peranan dalam ekosistem yang berfungsi sebagai pelindung terhadap hempasan gelombang dan arus (Tarigan, 2008).

Kawasan pesisir Kabupaten Kota Tidore Kepulauan memiliki keanekaragaman mangrove yang cukup tinggi, hal ini berdasarkan penelitian yang dilakukan di pesisir Desa Kaiyasa (Haji, 2014) dan Akbar et al (2016) di Pulau Mare. Informasi ekosistem mangrove dikawasan pesisir Kota Tidore Kepulauan juga dilaporkan LIPI (2015) menunjukan bahwa ekosistem mangrove memiliki persentase tutupan sedang. Selain itu DKP Tidore Kepualaun (2012) melaporkan dalam hasil identifikasi dan inventarisasi potensi mangrove menemukan 12 jenis mangrove yang tersebar di seluaruh Kota Tidore Kepulauan. Bappedas (2010) melaporkan bahwa luas areal mangrove di Tidore Kepualan sebesar 1.492,03 Ha. Namun tidak melaporkan informasi tentang stuktur komunitas pada daerah ini, hal ini memberikan padangan bahwa perlu adanya penelitian terkait yang berlokasi dikawasan pesisir lainnya. Informasi struktur komunitas ekosistem mangrove di Pulau Sibu hingga 
kini belum dilaporkan. Sehingga perlu adanya penelitian secara detail dan berkelanjutan untuk memperoleh data dan informasi terkini ekosistem mangrove. Penelitian berkaitan dengan struktur komunitas ekosistem mangrove penting dilakukan, karena dapat memberikan gambaran status dan dijadikan basis data pengelolaan mangrove.

\section{MATERI DAN METODE}

\section{Lokasi Sampling}

Penelitian dilaksanakan pada bulan Oktober-November 2017 di Pulau Sibu, kecamatan Oba Utara, Kota Tidore Kepulauan. Provinsi Maluku Utara (Gambar 1). Tahapan penelitian dimulai survey awal, pengambilan data lapang, tabulasi data, analisis dan pembuatan laporan.

\section{Teknik Pengambilan Data}

Stasiun penelitian ditetapkan sebanyak 3 stasiun, yang meliputi bagian utara, selatan dan timur Pulau Sibu.Pengambilan contoh mangrove, di lakukan dengan menggunakan metode transect quadrant (Bengen, 2004). Pada setiap stasiun transek di tarik tegak lurus dari arah laut ke darat sepanjang 50 meter sebanyak 3 lintasan dengan jarak antara lintasan 20 meter. Pada setiap transek, data vegetasi di cuplik dengan menggunakan 3 kuadrat yang berdekatan $(10 \mathrm{~m} \times 10 \mathrm{~m})$ dan dalam kuadrant tersebut di susun 4 kuadrat $(5 \mathrm{~m} \times 5 \mathrm{~m})$ untuk pengamatan anakan dan 10 kuadrat kecil $(1 \mathrm{~m} \times 1 \mathrm{~m})$. Selain itu juga pengambilan contoh mangrove, juga dilakukan dengan menggunakan metode "spot check" (Bengen, 2004). Metode ini digunakan untuk melengkapi informasi komposisi jenis, distribusi jenis, dan kondisi umum ekosistem mangrove yang tidak teramati pada metode transek-kuadrat. Metode ini dilakukan dengan cara mengamati dan memeriksa zona-zona tertentu dalam ekosistem mangrove yang memiliki ciri khusus. Informasi yang diperoleh melalui metode ini bersifat deskriptif.

Data hasil pengambilan mangrove kemudian dicatat dan di masukan kedalam tabel pencatat. Pencatatan data sesuai dengan kategori pertumbuhan mangrove yaitu :

- Kategori pohon : diameter batang $>4 \mathrm{~cm}$

- Kategori anakan : diameter $<4 \mathrm{~cm}$ dan tinggi $>1 \mathrm{~m}$

- Kategori semaian : tinggi $<1 \mathrm{~m}$

Keperluan identifikasi vegetasi mangrove di ambil contoh biologis berupa komponen daun, bunga, dan buah serta diukur lingkaran batang setiap pohon mangrove setinggi dada.Identifikasi tumbuhan mangrove berdasarkan pedoman Noor et al (2012). 


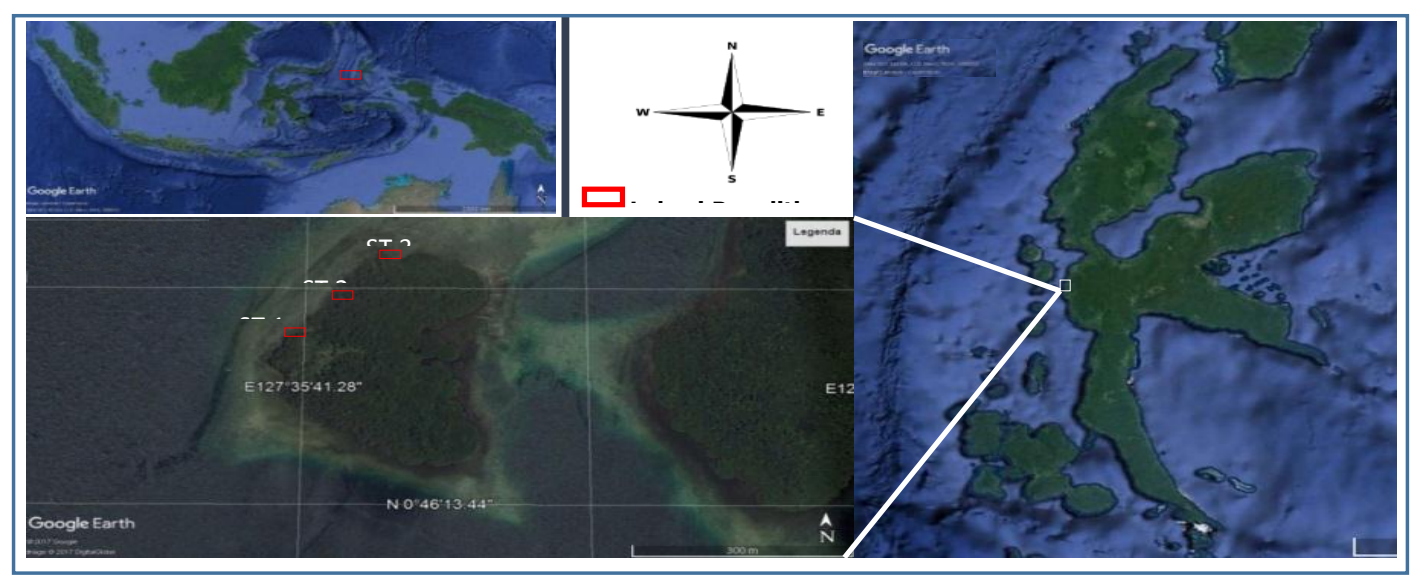

Gambar 1. Peta Lokasi Penelitian Pulau Sibu

\section{Analisis Data}

Analisa data yang digunakan untuk menentukan kondisi hutan mangrove dengan menggunakan analisa kerapatan jenis, frekuensi jenis, luas areal penutupan, nilai penting jenis (Bengen, 2004) dan keanekaragaman jenis Indeks Shannon-Winner (Odum 1971; Krebs 1985).

\section{HASIL DAN PEMBAHASAN}

\section{Parameter Lingkungan}

Hasil pengukuran parameter hidrologi menunjukan bahwa lingkungan didaerah tersebut tergolong baik dimana meliputi suhu, salinitas, $\mathrm{pH}$ air dan $\mathrm{pH}$ tanah (Tabel 1). Pulau Sibu terdapat tiga ekosistem utama yakni ekosistem mangrove, lamun dan terumbu karang. Terumbu karang dan lamun secara merata terdistribusi mengelilingi pulau, namun ekosistem mangrove hanya tersdistribusi pada bagian barat Pulau Sibu.

Tabel 1. Hasil Pengukuran Parameter Lingkungan

\begin{tabular}{cclcc}
\hline No & Lingkungan & Parameter & Nilai & Satuan \\
\hline 1 & & Suhu & 29 & ${ }^{0} \mathrm{C}$ \\
2 & Perairan & Salinitas & 35 & $\%$ oo \\
3 & & $\mathrm{pH}$ air & 7 & - \\
4 & & $\mathrm{pH}$ tanah & 6 & - \\
5 & Tanah & Lumpur Berpasir & - & - \\
\hline
\end{tabular}

Suhu merupakan salah satu parameter yang penting bagi keberlangsungan hidup biota laut. Suhu dapat mempengaruhi prosesproses seperti fotosentesis dan respirasi (Aksornkoae, 1993). Kusmana 
(1995) mengatakan bahwa pertumbuhan mangrove yang baik memerlukan suhu rata-rata minimal lebih besar dari $20{ }^{\circ} \mathrm{C}$. Kisaran nilai suhu perairan yang sama juga ditemukan Kushartono (2009) di desa Pasar Banggai Kabupaten Rembang, Harahap dan Mahmudi (2014) di pesisir Kecamatan Gending Kabupaten Probolinggo, kemudian Agustini et al (2016) di desa Kahyapu Pulau Enggano serta Akbar et al (2017) di Teluk Dodinga Kabupaten Halmahera Barat.

Salinitas merupakan faktor penting dalam pertumbuhan, daya tahan dan zonasi jenis mangrove. Nilai salinitas menunjukan tidak terdapat perbedaan signifikan antar setiap lokasi. Akbar et al (2017) mengatakan salinitas merupakan faktor penting dalam pertumbuhan, daya tahan dan zonasi jenis mangrove. Sedangkan Muryani (2009) menyebutkan bahwa dari banyak faktor lingkungan, salinitas mempunyai pengaruh besar pada perkembangan hutan mangrove. Menurut Supriharyono (2002) menjelaskan bahwa kisaran salinitas pada hutan mangrove berkisar antar 10- 30 ppt. Berdasarkan hasil pengukuran, ditemukan nilai salinitas yang sesusi dengan kondisi habitat untuk tumbuh dan berkembangnya hutan mangrove. Hasil pengukuran yang sama ditemukan Akbar et al (2017) di Teluk Dodinga, Kabupaten Halmahera Barat. Kadar salinitas peraiaran cenderung stabil disebabkan tidak adanya aliran sungai yang masuk disekitar pulau Sibu. Hal berbeda ditemukan oleh Setiawan (2013) yang menemukan kadar salinitas rendah di daerah desa Tongke-Tongke, Pasimarannu dan Panaikang, hal ini disebabkan karena adanya pengaruh masukan air tawar dari daratan melalui sungai.

Pengukuran $\mathrm{pH}$ tanah dan air menunjukkan semua lokasi termasuk dalam kategori sangat baik. Data yang peroleh, jika dibandingkan dengan standar yang ditetapkan Keputusan Menteri Lingkungan Hidup KEP No. $51 / \mathrm{MNLH} / \mathrm{I} / 2004$, berkisar antara 6.5- 8.5 (MNLH, 2004). Laporan Akbar et al (2017) di Teluk Dodinga, Kabupaten Halmahera Barat menemukan bahwa kondisi $\mathrm{pH}$ yang ditemukan sesuai dengan standar baku butu yang ditetapkan. Sedangkan hal yang berbeda ditemukan Setiawan (2013) dimana terjadi pengasaman nilai $\mathrm{pH}$ di esa Tongke-Tongke, Desa Panaikang dan Desa Pasimarannu. Menurut Hakim (2009) dan Setiawan (2013) nilai $\mathrm{pH}$ yang agak masam, dikarenakan adanya perombakan serasah vegetasi mangrove oleh mikroorganisme tanah yang menghasilkan asam-asam organik sehingga menurunkan $\mathrm{pH}$ tanah. Sedangkan Hardjowigeno (1987) mengatakan bahwa tanah - tanah bertekstur liat mempunyai luas permukaan yang lebih besar sehingga kemampuan menahan air dan menyediakan unsur hara tinggi, tetapi oksigen tidak begitu banyak.

\section{Ketebalan Hutan Mangrove}

Ketebalan hutan mangrove dikawasan teluk Pulau Sibu berdasarkan pengamatan adalah 410 meter (Stasiun I), 321 meter (Stasiun II), 389 meter (Stasiun III). Ketebalan hutan mangrove dapat dilihat pada Gambar 2. 


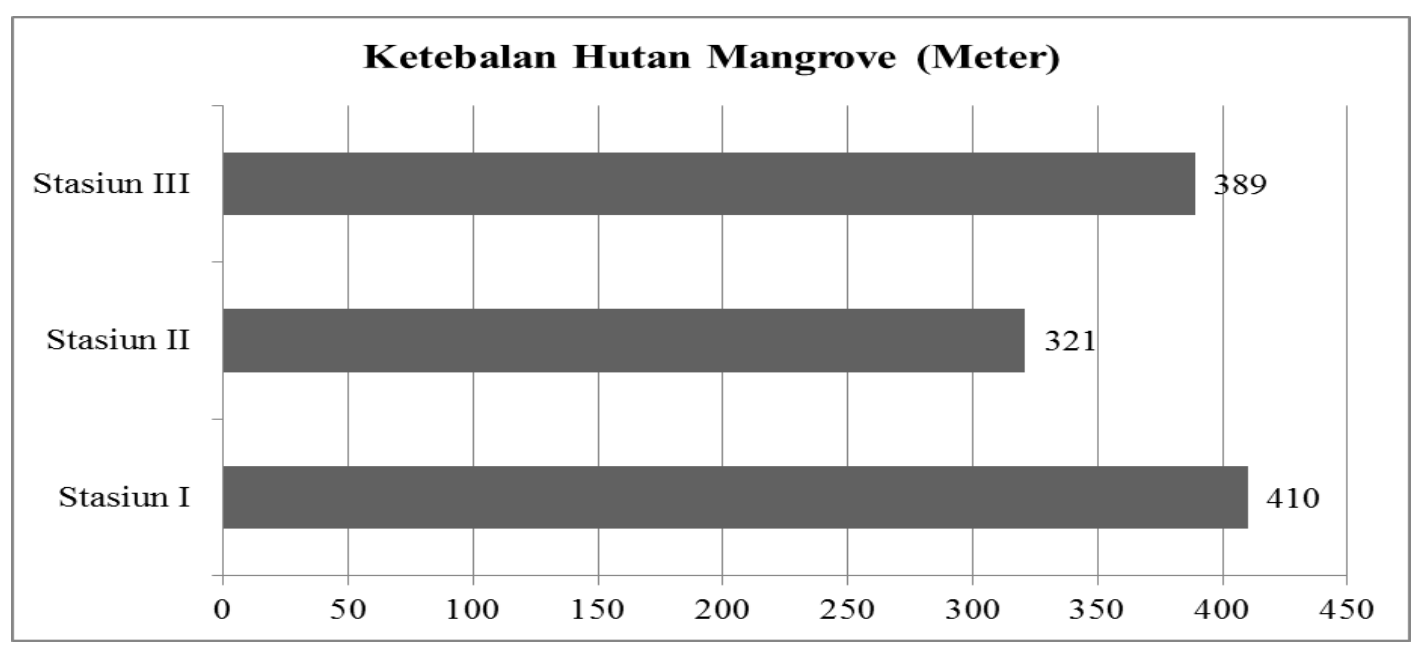

Gambar 2. Ketebalan Hutan Mangrove di Teluk Pulau Sibu

Perbedaan variasi ini diakibatkan karena setiap stasiun memiliki tipe pantai yang berbeda (Akbar et al, 2016). Keseluruhan lokasi penelitian berada pada bagian barat pulau. Pemilihan lokasi ini dikarenakan pada bagian ini pasang air yang masuk lebih jauh ketimbang pada bagian barat pulau, dengan demikian akan mempengaruhi distribusi mangrove. Lokasi penelitian stasiun I merupakan daerah tanjung yang berdekatan pada bagian selatan dengan daratan utama. Ketebalan mangrove disebabkan karena rataan pantai memanjang jauh dari daratan.

Pada stasiun II terletak dibagian tengah pulau yang berbentuk seperti teluk. Lokasi ini distribusi mangrove tidak merata seperti stasiun I, dimana mangrove terletak pada bagian dalam pulau. Sedangkan pada stasiun III terletak pada bagian ujung barat pulau yang menjorok kelaut (tanjung) dengan tingkat ketebalan yang tinggi. Secara umum variasi ketebalan mangrove yang ditemukan tidak begitu berbeda, namun disebabkan karena topografie daratan yang menjorok jauh kearah pantai dan kontur pantai yang landai. Akbar (2015) mengatakan pada daerah yang landai memiliki ruang yang luas untuk ditumbuhi oleh mangrove sehingga distribusi jenis mangrove meluas dan melebar. Hasil penelitian yang sama juga dilaporkan Setiawan (2013) yang menemukan tingkat ketebalan tinggi (200-300 meter) yang berlokasi di Desa Tongke-Tongke, mangrove dengan tingkat ketebalan sedang (100-150 meter) yang berlokasi di Desa Panaikang, Akbar et al (2016) menemukan hal berbeda dimana diperoleh ketebalan mangrove berkisar 85-150 meter di Pulau Mare, Kota Tidore Kepulauan.

\section{Komposisi Jenis Mangrove}

Pengamatan lapangan berdasarkan identifikasi moforlogi seperti ciri dari bentuk akar, buah dan daun, maka diperoleh sebanyak 10 jenis dari 4 famili (Tabel 2). Karakteristik pulau dengan ciri pantai landai dan luas kearah laut memberikan tempat untuk hidup dan berkembangnya 
mangrove. Kusmana (2003) menyatakan bahwa topografi dapat mempengaruhi komposisi jenis, distribusi jenis dan lebar hutan mangrove. Selanjutnya Fajar et al (2013) mengatakan kemiringan alas atau topografi mempengaruhi distribusi dan lebar hutan mangrove. Selain karakteristik oseanografie dan keadaan substrat yang sesuai akan memberikan peluang kehadiran jenis mangrove yang tinggi di daerah pantai. pada tiap stasiun menunjukkan adanya keseragaman tipe topografi pada daerah pantai di lokasi penelitian.

Tabel 2. Komposisi Jenis Mangrove di Pulau Sibu

\begin{tabular}{|c|c|c|c|c|}
\hline No & Famili & Jenis & Nama Indonesia & Nama lokal \\
\hline \multirow[t]{7}{*}{1} & Rhizophoraceae & $\begin{array}{l}\text { Rhizophora } \\
\text { stylosa }\end{array}$ & Bakau Merah & Soki-Soki \\
\hline & & $\begin{array}{l}\text { Rhizophora } \\
\text { apiculata }\end{array}$ & Bakau & \\
\hline & & Rhizophora & Bakau hitam & \\
\hline & & $\begin{array}{l}\text { mucronata } \\
\text { Ceriops } \\
\text { zippeliana }\end{array}$ & & \\
\hline & & Ceriops stagal & $\begin{array}{l}\text { Tengar/ M. } \\
\text { Kuning }\end{array}$ & \\
\hline & & $\begin{array}{l}\text { Bruguiera } \\
\text { gymnorrhiza }\end{array}$ & Tanjang & \\
\hline & & $\begin{array}{l}\text { Bruguiera } \\
\text { cylindrica }\end{array}$ & Tancang & \\
\hline 2 & Meliaceae & $\begin{array}{l}\text { Xylocarpus } \\
\text { granatum }\end{array}$ & M. Apel/Nyirih & Posi-Posi \\
\hline 3 & Sonneratiaceae & Sonneratia alba & Pedada & Posi-Posi \\
\hline 4 & Myrsinaceae & $\begin{array}{l}\text { Aegiceras } \\
\text { froridum }\end{array}$ & Semak & Soki-Soki \\
\hline
\end{tabular}

Tabel 3. Komposisi Jenis Mangrove di Stasiun 1

\begin{tabular}{clcccc}
\hline \multirow{2}{*}{ No } & \multicolumn{1}{c}{ Jenis } & \multicolumn{3}{c}{ Kategori pertumbuhan } & \multirow{2}{*}{ Jumlah } \\
\cline { 3 - 5 } & Pohon & Anakan & Semaian & \\
\hline 1 & Rhizophora stylosa & 78 & 21 & 16 & 115 \\
2 & $\begin{array}{l}\text { Rhizophora apiculata } \\
\text { Rhizophora }\end{array}$ & 65 & 17 & 18 & 100 \\
3 & mucronata & 69 & 17 & 26 & 112 \\
4 & Ceriops zippeliana & 3 & 0 & 1 & 4 \\
5 & Ceriops stagal & 8 & 1 & 1 & 10 \\
& Bruguiera & 14 & 2 & 6 & 22 \\
6 & gymnorrhiza & 11 & 3 & 2 & 16 \\
7 & Bruguiera cylindrica & & & & \\
8 & Xylocarpus granatum & 6 & 1 & 1 & 8
\end{tabular}




\begin{tabular}{clcccc}
9 & Sonneratia alba & 25 & 4 & 3 & 32 \\
10 & Aegiceras froridum & 16 & 2 & 3 & 21 \\
& & 295 & 56 & 70 & 440 \\
\hline
\end{tabular}

Tabel 4. Komposisi Jenis Mangrove di Stasiun 2

\begin{tabular}{clccccc}
\hline \multirow{2}{*}{ No } & \multicolumn{1}{c}{ Jenis } & \multicolumn{4}{c}{ Kategori pertumbuhan } & \multirow{2}{*}{ Jumlah } \\
\cline { 3 - 5 } & Rhizophora stylosa & 104 & 26 & 19 & 149 \\
\hline 1 & Rhizophora & & & Semaian & \\
& Rhizoph & & & & \\
2 & mucronata & 96 & 18 & 21 & 125 \\
3 & Ceriops stagal & 9 & 3 & 2 & 14 \\
4 & Bruguiera cylindrica & 6 & 3 & 3 & 12 \\
5 & Xylocarpus granatum & 8 & 3 & 2 & 13 \\
6 & Sonneratia alba & 19 & 5 & 2 & 26 \\
& & 232 & 47 & 45 & 339 \\
\hline
\end{tabular}

Identifikasi dan pengamatan ditemukan bahwa jenis mangrove dari Famili Rhizophoraceae paling dominan yakni 7 jenis dan famili Sonneratiaceae, Meliaceae dan Myrsinaceae hanya ditemukan 1 jenis (Tabel 2). Jenis famili Rhizophoraceae paling dominanan. Menurut Akbar et al $(2015 ; 2016 ; 2017)$ disebabkan peluang ditemukannya jenis dari famili ini tiap kuadran lebih banyak, selain itu habibat turut mendukung aspek ekologi, biologi dan fisologi dari famili ini (Tabel 3,4,5). Laporan Akbar et al $(2015,2016,2017 a, 2017 b)$ memperoleh hasil yang sama, dimana famili Rhizophoraceae paling dominanan pada Pulau Mare Kota Tidore Kepulauan, Pesisir Sidangoli Kabupaten Halmahera Barat, Pulau Maitara Tidore Kepulauan dan Teluk Dodinga Kabupaten Halmahera Barat. Laporan Agustina et al (2016) menyebutkan bahwa jenis ini juga ditemukan pada Pulau Enggano.

Tabel 5. Komposisi Jenis Mangrove di Stasiun 3

\begin{tabular}{|c|c|c|c|c|c|}
\hline \multirow{2}{*}{ No } & \multirow{2}{*}{ Jenis } & \multicolumn{3}{|c|}{ Kategori pertumbuhan } & \multirow{2}{*}{ Jumlah } \\
\hline & & Pohon & Anakan & Semaian & \\
\hline 1 & Rhizophora stylosa & 87 & 12 & 22 & 121 \\
\hline 2 & $\begin{array}{l}\text { Rhizophora apiculata } \\
\text { Rhizophora }\end{array}$ & 75 & 17 & 12 & 104 \\
\hline 3 & mucronata & 98 & 8 & 9 & 115 \\
\hline 4 & $\begin{array}{l}\text { Ceriops stagal } \\
\text { Bruguiera }\end{array}$ & 9 & 3 & 2 & 14 \\
\hline 5 & gymnorrhiza & 14 & 2 & 6 & 22 \\
\hline 6 & Bruguiera cylindrica & 8 & & 2 & 10 \\
\hline 7 & Sonneratia alba & 26 & 2 & 1 & 29 \\
\hline 8 & Aegiceras froridum & $\begin{array}{c}11 \\
328\end{array}$ & $\begin{array}{c}4 \\
40\end{array}$ & $\begin{array}{c}5 \\
53\end{array}$ & $\begin{array}{c}20 \\
435\end{array}$ \\
\hline
\end{tabular}




\section{Struktur Komunitas dan Vegetasi Mangrove}

Nilai struktur komunitas dan vegetasi mangrove berdasarkan stasiun pengamatan diperoleh $24,44 \mathrm{ind} / \mathrm{m}^{2}$ dan diikuti oleh stasiun II dengan nilai $24,17 \mathrm{ind} / \mathrm{m}^{2}$ dan terendah pada stasiun III yaitu 18,83 ind $/ \mathrm{m}^{2}$. Kategori peluang kehadiran jenis ditemukan paling tinggi terdapat pada stasiun I yakni $5,00 \mathrm{ind} / \mathrm{m}^{2}$, kemudian stasiun III dengan nilai 4,17 ind $/ \mathrm{m}^{2}$ dan stasiun III yakni $2,83 \mathrm{ind} / \mathrm{m}^{2}$. Persentasi tutupan tertinggi vegetasi mangrove ditemukan pada stasiun stasiun I yaitu 18,19 , disusul stasiun III sebesar 15,29 dan terendah stasiun III dengan nilai 12,49. Kategori nilai penting untuk keseluruhan stasiun memiliki nilai sama yaitu $300 \%$ (Tabel 6).

Tabel 6. Struktur Komunitas Hutan Mangrove per Stasiun

\begin{tabular}{llll}
\hline \multicolumn{1}{c}{ Jumlah Total } & \multicolumn{1}{c}{ Stasiun 1} & \multicolumn{1}{c}{ Stasiun 2 } & \multicolumn{1}{c}{ Stasiun 3 } \\
\hline $\mathrm{Di}$ & $24,44 \mathrm{ind} / \mathrm{m}^{2}$ & $18,83 \mathrm{ind} / \mathrm{m}^{2}$ & $24,17 \mathrm{ind} / \mathrm{m}^{2}$ \\
$\mathrm{Rdi}$ & $100 \%$ & $100 \%$ & $100 \%$ \\
$\mathrm{Fi}$ & $5,00 \mathrm{ind} / \mathrm{m}^{2}$ & $2,83 \mathrm{ind} / \mathrm{m}^{2}$ & $4,17 \mathrm{ind} / \mathrm{m}^{2}$ \\
$\mathrm{Fri}$ & $100 \%$ & $100 \%$ & $100 \%$ \\
$\mathrm{Ci}$ & 18,19 & 12,49 & 15,29 \\
$\mathrm{Rci}$ & $100 \%$ & $100 \%$ & $100 \%$ \\
$\mathrm{NP}$ & $300 \%$ & $300 \%$ & $300 \%$ \\
\hline
\end{tabular}

Nilai kerapatan yang tinggi pada stasiun I dan III dikarenakan kondisi topografie pantai yang dangkal dan melebar ke arah laut. Hal ini memungkinkan mangrove untuk tumbuh lebih padat dan luas. Selain itu keberadaan substrat yang cocok terhadap pertumbuhan mangrove, tingkat pemanfaatan masyarakat rendah, Sedangkan pada stasiun II ditemukan kondisi topografie pantai yang dalam dengan jarak lebar pantai yang lebih pendek. Pada lokasi ini dtemukan bagan dan bubu yang diletakan masyarakat untuk mencari ikan. Secara keseluruhan aktivitas pemanfaatan mangrove pada ketiga stasiun rendah, masyarakat melakukan pemanfaatan batang mangrove untuk kebutuhan tongkat pengikat perahu, jembatan dan kayu bakar dengan intensitas yang rendah dan waktu yang lama.

Laporan penelitian Akbar et al (2016;2017a;2017b) pada daerah Teluk Dodinga, Pulau Maitara dan Pulau Mare bahwa terdapat beragam pemanfaatan mangrove untuk kebutuhan masyarakat, selain itu juga ditemukan tingkat pemahaman masyarakat terhadap manfaat mangrove cukup baik.

\section{Indeks Ekologi Mangrove}

Nilai hasil analisis kerapatan relatif, frekuensi, tutupan dan nilai penting jenis pada setiap stasiun dilihat pada (Tabel 7, 8 dan 9). Jenis 
Kerapatan tertinggi yang diperoleh Rhizophora stylosa, dikarenakan kondisi pantai menyediakan ruang ekologi dan biologi yang cocok, hal lain yang diemukan bahwa aktivitas pemanfaatan pada jenis ini sangat rendah dan kemampuan beradaptasi dengan lingkungan yang tinggi. Famili Rhizophoraceae pada Pulau Sibu terletak tepat pada bagian depan menghadap ke laut dengan kondisi habitat selalu tergenang air. Sebagaimana dikemukakan Nybakken (1988) zona Rhizopora terletak pada tepi yang menghadap ke arah laut. Hal yang sama juga ditemukan Akbar et al $(2015 ; 2016 ; 2017 a ; 2017 b)$ di pesisir Pulau Sidangoli, Pulau Mare, Teluk Dodinga dan Pulau Maitara. Selain itu juga ditemukan Agustini et al (2016) di Desa Kahyapu Pulau Enggano, Sumatera. Kondisi lingkungan lumpur berpasir akan mendukung kehadiran dan merupakan tempat tumbuh berkembang famili Rhizophoraceae (Ernanto et al, 2010; Noor et al, 2012). Kerapatan dari suatu jenis merupakan nilai yang menunjukkan jumlah atau banyaknya individu suatu jenis per satuan luas. Makin besar kerapatan suatu jenis, makin banyak individu jenis tersebut per satuan luas (Bengen, 2004).

Tabel 7. Struktur Komunitas Hutan Mangrove pada Stasiun I

\begin{tabular}{|c|c|c|c|c|c|c|c|c|}
\hline \multirow{2}{*}{ No } & \multirow{2}{*}{ Jenis } & \multicolumn{7}{|c|}{ Indeks Ekologi } \\
\hline & & $\mathrm{Di}$ & Rdi & $\mathrm{Fi}$ & Fri & $\mathrm{Ci}$ & Rci & NP \\
\hline 1 & $\begin{array}{l}\text { Rhizophora } \\
\text { stylosa }\end{array}$ & 6,39 & $\begin{array}{c}26,1 \\
4\end{array}$ & $\begin{array}{c}1,0 \\
0\end{array}$ & $\begin{array}{c}20,6 \\
9\end{array}$ & 2,4 & 13 & $\begin{array}{c}60,0 \\
2\end{array}$ \\
\hline 2 & $\begin{array}{l}\text { Rhizophora } \\
\text { apiculata }\end{array}$ & 5,56 & $\begin{array}{c}22,7 \\
3\end{array}$ & $\begin{array}{c}0,8 \\
3\end{array}$ & $\begin{array}{c}17,2 \\
4\end{array}$ & 2,1 & $\begin{array}{c}11,5 \\
4\end{array}$ & $\begin{array}{c}51,5 \\
1\end{array}$ \\
\hline 3 & $\begin{array}{l}\text { Rhizophora } \\
\text { mucronata }\end{array}$ & 6,22 & $\begin{array}{c}25,4 \\
5\end{array}$ & $\begin{array}{c}0,5 \\
0\end{array}$ & $\begin{array}{c}10,3 \\
4\end{array}$ & 2,2 & $\begin{array}{c}12,0 \\
9\end{array}$ & $\begin{array}{c}47,8 \\
9\end{array}$ \\
\hline 4 & $\begin{array}{l}\text { Ceriops } \\
\text { zippeliana }\end{array}$ & 0,22 & 0,91 & $\begin{array}{c}0,3 \\
3\end{array}$ & 6,90 & 1,1 & 6,05 & $\begin{array}{c}13,8 \\
5\end{array}$ \\
\hline 5 & Ceriops stagal & 0,56 & 2,27 & $\begin{array}{c}0,5 \\
0\end{array}$ & $\begin{array}{c}10,3 \\
4\end{array}$ & 1,2 & 6,60 & $\begin{array}{c}19,2 \\
1\end{array}$ \\
\hline 6 & $\begin{array}{l}\text { Bruguiera } \\
\text { gymnorrhiza }\end{array}$ & 1,22 & 5,00 & $\begin{array}{c}0,6 \\
7\end{array}$ & $\begin{array}{c}13,7 \\
9\end{array}$ & 1,2 & 6,60 & $\begin{array}{c}25,3 \\
9\end{array}$ \\
\hline 7 & $\begin{array}{l}\text { Bruguiera } \\
\text { cylindrica }\end{array}$ & 0,89 & 3,64 & $\begin{array}{c}0,3 \\
3\end{array}$ & 6,90 & 1,4 & 7,64 & $\begin{array}{c}18,1 \\
7\end{array}$ \\
\hline 8 & $\begin{array}{l}\text { Xylocarpus } \\
\text { granatum }\end{array}$ & 0,44 & 1,82 & $\begin{array}{c}0,3 \\
3\end{array}$ & 6,90 & 1,8 & 9,90 & $\begin{array}{c}18,6 \\
1\end{array}$ \\
\hline 9 & Sonneratia alba & 1,78 & 7,27 & $\begin{array}{c}0,1 \\
7\end{array}$ & 3,45 & 3,5 & $\begin{array}{c}19,2 \\
4\end{array}$ & $\begin{array}{c}29,9 \\
6\end{array}$ \\
\hline 10 & $\begin{array}{l}\text { Aegiceras } \\
\text { froridum }\end{array}$ & 1,17 & 4,77 & $\begin{array}{c}0,1 \\
7\end{array}$ & 3,45 & 1,3 & 7,15 & $\begin{array}{c}15,3 \\
7\end{array}$ \\
\hline & & $\begin{array}{c}24,4 \\
4\end{array}$ & 100 & $\begin{array}{c}4,8 \\
3\end{array}$ & 100 & $\begin{array}{c}18,1 \\
9\end{array}$ & 100 & 300 \\
\hline
\end{tabular}

Jenis Kerapatan tertinggi yang diperoleh Rhizophora stylosa, dikarenakan kondisi pantai menyediakan ruang ekologi dan biologi yang 
cocok, hal lain yang diemukan bahwa aktivitas pemanfaatan pada jenis ini sangat rendah dan kemampuan beradaptasi dengan lingkungan yang tinggi. Famili Rhizophoraceae pada Pulau Sibu terletak tepat pada bagian depan menghadap ke laut dengan kondisi habitat selalu tergenang air. Sebagaimana dikemukakan Nybakken (1988) zona Rhizopora terletak pada tepi yang menghadap ke arah laut. Hal yang sama juga ditemukan Akbar et al $(2015 ; 2016 ; 2017 a ; 2017 b)$ di pesisir Pulau Sidangoli, Pulau Mare, Teluk Dodinga dan Pulau Maitara. Selain itu juga ditemukan Agustini et al (2016) di Desa Kahyapu Pulau Enggano, Sumatera. Kondisi lingkungan lumpur berpasir akan mendukung kehadiran dan merupakan tempat tumbuh berkembang famili Rhizophoraceae (Ernanto et al, 2010; Noor et al, 2012). Kerapatan dari suatu jenis merupakan nilai yang menunjukkan jumlah atau banyaknya individu suatu jenis per satuan luas. Makin besar kerapatan suatu jenis, makin banyak individu jenis tersebut per satuan luas (Bengen, 2004).

Tabel 8. Struktur Komunitas Hutan Mangrove pada Stasiun II

\begin{tabular}{|c|c|c|c|c|c|c|c|c|}
\hline \multirow{2}{*}{ No } & \multirow{2}{*}{ Jenis } & \multicolumn{7}{|c|}{ Indeks Ekologi } \\
\hline & & $\mathrm{Di}$ & Rdi & $\mathrm{Fi}$ & Fri & $\mathrm{Ci}$ & Rci & NP \\
\hline 1 & $\begin{array}{l}\text { Rhizophora } \\
\text { stvlosa }\end{array}$ & 8,28 & $\begin{array}{c}43,9 \\
5\end{array}$ & $\begin{array}{c}1,0 \\
0\end{array}$ & $\begin{array}{c}35,2 \\
9\end{array}$ & 2,4 & 19 & $\begin{array}{c}98,4 \\
6\end{array}$ \\
\hline 2 & $\begin{array}{l}\text { Rhizophora } \\
\text { mucronata }\end{array}$ & 6,94 & $\begin{array}{c}36,8 \\
7\end{array}$ & $\begin{array}{c}0,8 \\
3\end{array}$ & $\begin{array}{c}29,4 \\
1\end{array}$ & 2,2 & $\begin{array}{c}17,6 \\
1\end{array}$ & $\begin{array}{c}83,9 \\
0\end{array}$ \\
\hline 3 & Ceriops stagal & 0,78 & 4,13 & $\begin{array}{c}0,3 \\
3\end{array}$ & $\begin{array}{c}11,7 \\
6\end{array}$ & 1,2 & 9,61 & $\begin{array}{c}25,5 \\
0\end{array}$ \\
\hline 4 & $\begin{array}{l}\text { Bruguiera } \\
\text { cylindrica }\end{array}$ & 0,67 & 3,54 & $\begin{array}{c}0,3 \\
3\end{array}$ & $\begin{array}{c}11,7 \\
6\end{array}$ & 1,4 & $\begin{array}{c}11,1 \\
3\end{array}$ & $\begin{array}{c}26,4 \\
3\end{array}$ \\
\hline 5 & $\begin{array}{l}\text { Xylocarpus } \\
\text { granatum }\end{array}$ & 0,72 & 3,83 & $\begin{array}{c}0,1 \\
7\end{array}$ & 5,88 & 1,8 & $\begin{array}{c}14,4 \\
1\end{array}$ & $\begin{array}{c}24,1 \\
3\end{array}$ \\
\hline 6 & Sonneratia alba & $\begin{array}{c}1,44 \\
18,8 \\
3\end{array}$ & 7,67 & $\begin{array}{c}0,1 \\
7 \\
2,8 \\
3\end{array}$ & 5,88 & $\begin{array}{c}12,4 \\
9\end{array}$ & $\begin{array}{c}28,0 \\
2 \\
100\end{array}$ & $\begin{array}{c}41,5 \\
7 \\
300\end{array}$ \\
\hline
\end{tabular}

Frekuensi jenis menggambarkan kesempatan ataupun kemungkinan dan peluang dapat tumbuh dan ditemukannya suatu jenis dalam suatu areal lokasi yang menjadi areal pengamatan (Akbar et al, 2015). Nilai frekuensi jenis yang diperoleh memperlihatkan bahwa peluang akan kehadiran mangrove disetiap lokasi sangat besar, selain itu kemunculan setiap jenis juga besar sehingga memberikan peluang akan kestabilan mangrove di lokasi ini. Kustanti (2011) jenis jenis Rhizopora apiculata merupakan kelompok vegetasi dominan yang dapat menyesuaikan diri dengan lingkungan. Hal yang sama juga ditemukan Akbar et al (2015;2016;2017a;2017b) di pesisir Pulau Sidangoli, Pulau Mare, Teluk Dodinga dan Pulau Maitara. Selain itu juga ditemukan Agustini et al (2016) di Desa Kahyapu Pulau Enggano, Sumatera. Peluang kehadiran yang 
besar menunjukan bahwa kondisi lingkungan sangat sesuai dengan habibat mangrove. Walsh (1974) dalam Supriharyono (2002) mengatakan substrat tanah menentukan kehidupan hutan mangrove, tipe substrat yang cocok untuk pertumbuhan hutan mangrove adalah lumpur lunak, yang mengandung silt clay dan bahan-bahan organik yang lembut. Secara keseluruhan penutupan jenis tertinggi setiap stasiun ditemukan pada Soneratia alba. Hal ini sangat berhubungan erat dengan lingkar batang pohon (Akbar et al., 2015). Dimana jenis ini memiliki ukuran lingkar batang yang besar, sehingga turut mempengaruhi penutupan pada setiap lokasi.

Nilai penting jenis yang ditemukan paling dominan pada Rhizophora, hal ini dikarenakan jenis ini paling dominan pada setiap lokasi. Selain itu tingkat kerapatan dan frekuensi jenis sangat tinggi, sehingga memberikan indeks paling berpengaruh didalam komunitas mangrove. Faktor lain adalah kurangnya ekploitasi pada jenis mangrove di Pulau Sibu. Akbar et al (2015) mengatakan bahwa Eksploitasi mangrove, habitat yang cocok dan kondisi perairan yang stabil adalah faktor-faktor yang dapat mempengaruhi besarnya nilai penting. Odum (1993) dalam Raymond dkk. (2010) pengaruh suatu populasi terhadap komunitas dan ekosistem tidak hanya bergantung pada jenis dari organinasi yang terlibat tetapi bergantung juga pada jumlah atau kepadatan populasi.

Keseluruhan hasil analisis keanekaragaman tingkat stasiun menunjukan adanya perbedaan nilai setiap stasiun pengamatan (Gambar 03). Berdasarkan kriteria keanekaragaman jenis, maka ketiga stasiun masuk dalam kriteria keanekaragaman sedang. Penelitian dengan hasil yang sama juga ditemukan Mukhlisi et al (2013) di Desa Sidodadi Kecamatan Padang Cermin Kabupaten Pesawaran, Provinsi Lampung. Kemudian Akbar et al (2017a), Teluk Dodonga, Kabupaten Halamhera Barat. Provinsi Maluku Utara.

Tabel 9. Struktur Komunitas Hutan Mangrove pada Stasiun III

\begin{tabular}{|c|c|c|c|c|c|c|c|c|}
\hline \multirow{2}{*}{ No } & \multirow{2}{*}{ Jenis } & \multicolumn{7}{|c|}{ Indeks Ekologi } \\
\hline & & $\mathrm{Di}$ & Rdi & $\mathrm{Fi}$ & Fri & $\mathrm{Ci}$ & Rci & NP \\
\hline \multirow[t]{2}{*}{1} & Rhizophora & 6,72 & 27,8 & 1,0 & 24,0 & 2,4 & 16 & 67,5 \\
\hline & stylosa & & 2 & 0 & 0 & & & 1 \\
\hline \multirow[t]{2}{*}{2} & Rhizophora & 5,78 & 23,9 & 0,8 & 20,0 & 2,1 & 13,7 & 57,6 \\
\hline & apiculata & & 1 & 3 & 0 & & 3 & 4 \\
\hline \multirow[t]{2}{*}{3} & Rhizophora & 6,39 & 26,4 & 0,8 & 20,0 & 2,2 & 14,3 & 60,8 \\
\hline & mucronata & & 4 & 3 & 0 & & 9 & 3 \\
\hline \multirow[t]{2}{*}{4} & Ceriops staqal & 0,78 & 3,22 & 0,5 & 12,0 & 1,2 & 7,85 & 23,0 \\
\hline & cerrops stagal & & & 0 & 0 & & & 7 \\
\hline \multirow[t]{2}{*}{5} & Bruguiera & 1,22 & 5,06 & 0,3 & 8,00 & 1,2 & 7,85 & 20,9 \\
\hline & gymnorrhiza & & & 3 & & & & 1 \\
\hline \multirow[t]{2}{*}{6} & Bruguiera & 0,56 & 2,30 & 0,3 & 8,00 & 1,4 & 9,09 & 19,3 \\
\hline & cylindrica & & & 3 & & & & 9 \\
\hline \multirow[t]{2}{*}{7} & Sonneratia alba & 1,61 & 6,67 & $\begin{array}{c}0,1 \\
7\end{array}$ & 4,00 & 3,5 & 22,8 & 33,5 \\
\hline & & & & 7 & & & 9 & 6 \\
\hline
\end{tabular}


Aegiceras

$4,60 \quad 0,1$

\section{8} froridum

$\begin{array}{ccccccc} & 4,60 & 0,1 & & & & 17,1 \\ 1,11 & & 7 & 4,00 & 1,3 & 8,50 & 0 \\ 24,1 & & 4,1 & & 15,2 & & \\ 7 & 100 & 7 & 100 & 9 & 100 & 300\end{array}$

Selain itu Agustini et al (2016) juga dimana tingkat keanekaragaman jenis mangrove masuk dalam kategori sedang di Pulau Enggano. Laporan yang berbeda ditemukan Akbar et al (2016 dan 2017b) di Pulau Mare dan Pulau Maitara, Kota Tidore Kepulauan dimana keanekakaragaman pada daerah ini rendah. Indriyanto (2006) keanekaragaman jenis juga dapat digunakan untuk mengukur stabilitas komunitas, yaitu kemampuan suatu komunitas untuk menjaga dirinya tetap stabil. Nilai keanekaragaman yang diperoleh memperlihatkan adanya variasi antar stasiun, hal ini disebabkan karena komposisi dan jumlah jenis yang ditemukan setiap lokasi berbeda-beda. Kaunang dan Kimbal (2009) bahwa keanekaragaman (biodiversity), suatu komunitas dikatakan memiliki keanekaragaman jenis yang tinggi jika komunitas tersebut disusun oleh banyak jenis, sebaliknya suatu komunitas dikatakan memiliki keanekaragaman jenis yang rendah jika komunitas itu disusun oleh sedikit jenis dan jika hanya ada sedikit saja jenis yang dominan.

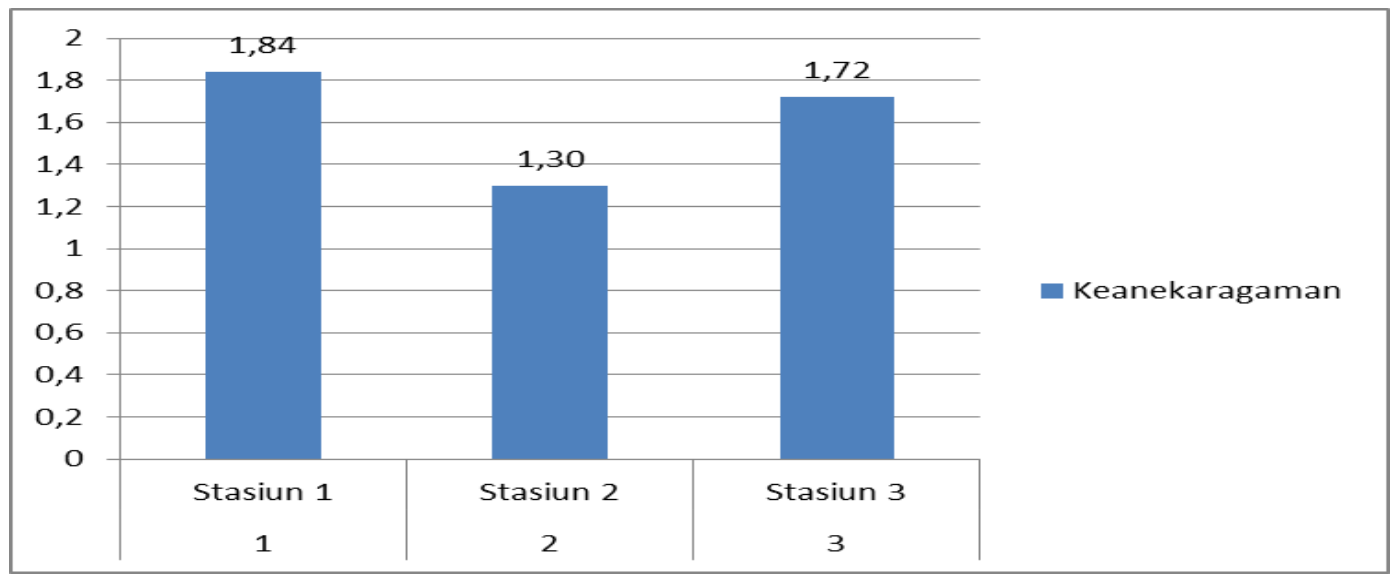

Gambar 3. Keanekaragaman Mangrove setiap Stasiun

Nilai indeks keanekaragaman jenis mangrove ini lebih redah dari Pulau Sebatik, Kalimantan Timur dengan H'=0,64-1,55 (Ardiansyah et al, 2012), kawasan hutan mangrove di Banyuasin, Sumatera Selatan dengan $H^{\prime}=0,34-0,88$ (Indriani et al, 2009), Agustini et al (2016) melaporkan nilai keankeragaman yang ditemukan di pulau Enggano berkisar antara 1,532,34 Akbar et al (2017b) di Teluk Dodinga, Kabupaten Halmahera Barat. Provinsi Maluku Utara dan lebih tinggi dari laporan Akbar et al (2017b) di Pulau Maitara, Kota Tidore Kepulauan dengan H'= yaitu 0.495 . Perbedaan hasil penelitian yang ditemukan diakibatkan perbedaan komposisi, jumlah,ekologi, morfologi pantai dan tingkat pemanfaatan pada setiap daerah pengamatan. Kondisi sosial ekonomi masyarakat turut memberikan kontribusi terhadap distribusi dan tingkat keberlangsungan 
hidup ekosistem mangrove. Pengetahuan akan pentingnya nilai ekologi dan kearifan lokal disuatu daerah, memberikan pengaruh terhadap ketersediaan ekosistem mangrove di wilayah pesisir. Tiap lokasi mangrove mempunyai keanekaragaman vegetasi yang berbeda, bergantung pada umur mangrove tersebut (Kjerfve dan Lacerda, 1993; Dodd et al., 1998; Gunarto, 2004). Perbedaan vegetasi tersebut kemungkinan disebabkan oleh perbedaan kondisi lingkungan seperti salinitas, suhu, pHdan substrat (Triatmodjo, 1999; Bengen, 2002; Kathiresan dan Bingham, 2001; Gunarto, 2004; Shan et al., 2008; Saru, 2009) .

Hasil analisis keanekaragaman jenis tiap stasiun ditemukan famili Rhizophoraceae yang terdiri dari Rhizophora stylosa, Rhizophora mucronata dan Rhizophora apiculata memiliki nilai keragaman paling tinggi diantara semua jenis (Gambar 04) Nilai keanekaragaman suatu komunitas sangat bergantung pada jumlah jenis dan jumlah individu yang terdapat pada komunitas tersebut. Secara alami keanekaragaman jenis hutan mangrove memang lebih rendah bila dibandingkan hutan tropis namun memiliki struktur dan fungsi yang mampu mempertahankan hidupnya pada lingkungan ekstrim di zona pasang surut (Duke et al, 1998). Ekosistem mangrove juga memiliki produktivitas primer yang tinggi namun dapat dengan mudah berubah bila ada gangguan terutama yang bersifat antropogenik (Hogart, 1998). Sebagian besar perubahan keanekaragaman jenis dan struktur vegetasi hutan mangrove disebabkan oleh aktivitas antropogenik pada kawasan pesisir (Alongi, 2002; Thampanya et al, 2006). Permasalahan tersebut terjadi pada hampir semua kawasan hutan mangrove terutama pada negara-negara berkembang termasuk di Indonesia.
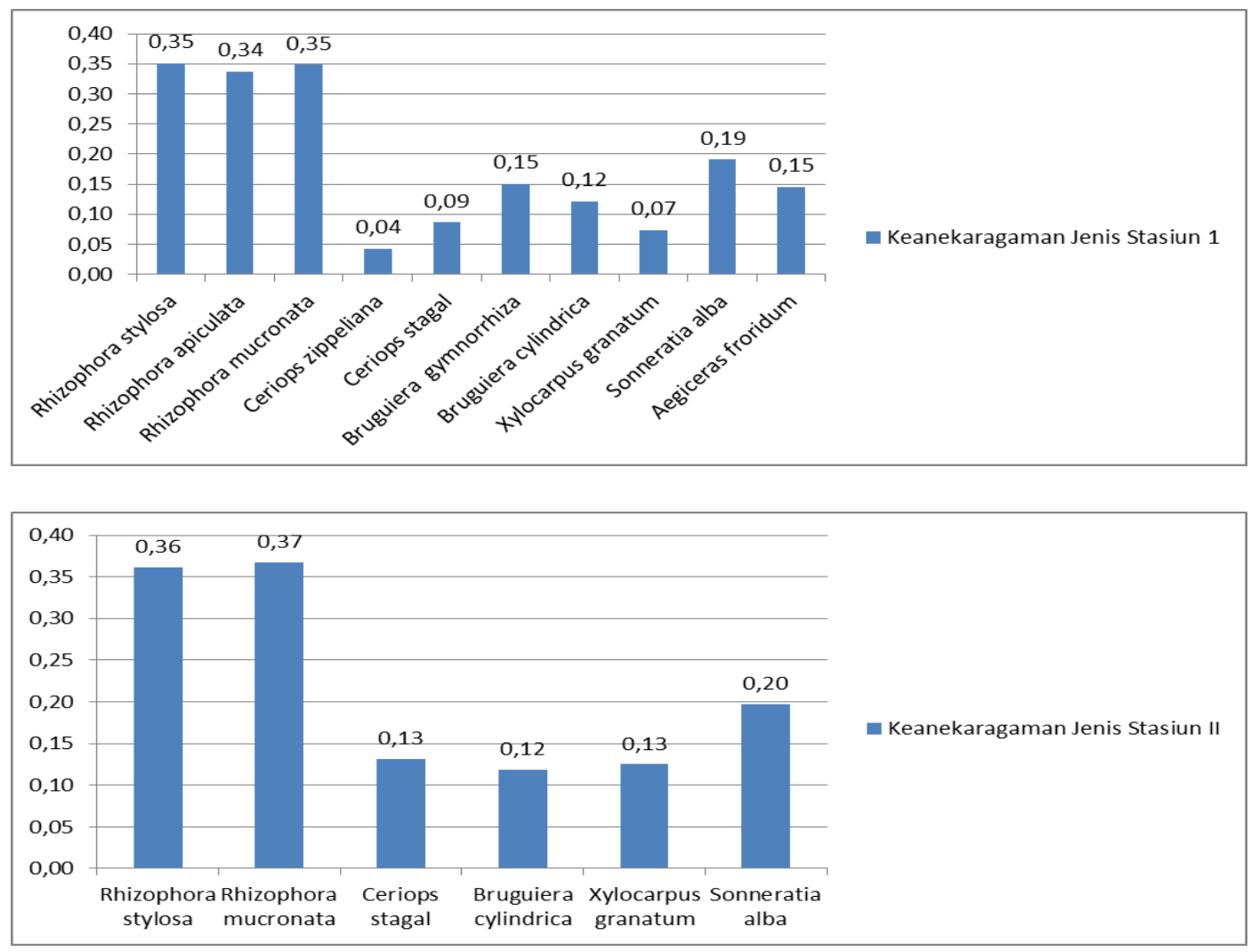


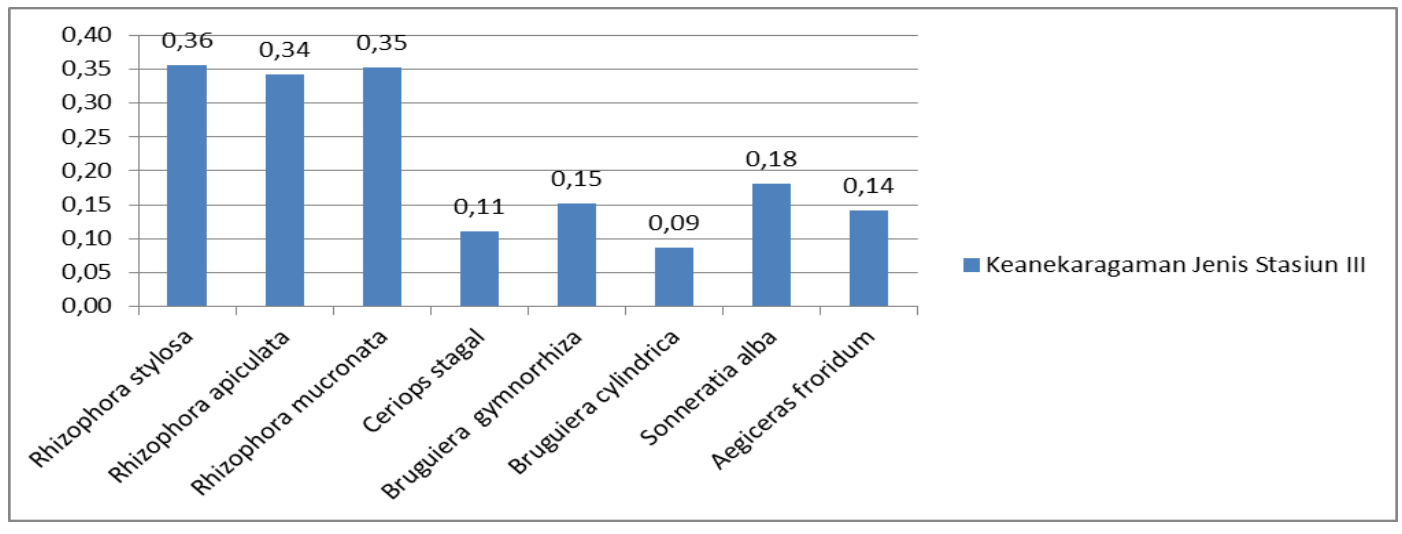

Gambar 4. Keanekaragaman Jenis Mangrove Stasiun I, II dan III

\section{KESIMPULAN DAN SARAN}

Kehadiran jenis mangrove hasil pengamatan dan identifikasi diperoleh sebanyak 10 jenis dari 4 famili. Nilai struktur komunitas dan vegetasi mangrove berdasarkan stasiun pengamatan diperoleh $24,44 \mathrm{ind} /$ $\mathrm{m}^{2}$ dan diikuti oleh stasiun II dengan nilai $24,17 \mathrm{ind} / \mathrm{m}^{2}$ dan terendah pada stasiun III yaitu $18,83 \mathrm{ind} / \mathrm{m}^{2}$. Kategori peluang kehadiran jenis ditemukan paling tinggi terdapat pada stasiun I yakni 5,00 ind $/ \mathrm{m}^{2}$, kemudian stasiun III dengan nilai 4,17 ind $/ \mathrm{m}^{2}$ dan stasiun III yakni 2,83 ind $/ \mathrm{m}^{2}$. Persentasi tutupan tertinggi vegetasi mangrove ditemukan pada stasiun stasiun I yaitu 18,19, disusul stasiun III sebesar 15,29 dan terendah stasiun III dengan nilai 12,49. Kategori nilai penting untuk keseluruhan stasiun memiliki nilai sama yaitu $300 \%$. Struktur komunitas hutan mangrove di Pulau Sibu berdasarkan indeks ekologi (nilai kerapatan, frekuensi jenis, tutupan dan nilai penting) cukup baik, sedangkan keanekaragaman spesies masngrove termasuk dalam kategori sedang.

Penerapan pola pemanfaatan, pengembangan dan upaya pelestarian terhadap ekosistem mangrove perlu dilakukan lebih komprehensif.

\section{UCAPAN TERIMA KASIH}

Penulis mengucapkan terimakasih kepada Program Pascasarjana Perikanan dan IImu Kelautan atas dana hibah yang diberikan untuk penelitian ini. Selain itu juga kepada aparatur dan masyarakat Desa Kaiyasa yang bersedia membantu penulis selama penelitian. 


\section{DAFTAR PUSTAKA}

Akbar, N., Baksir, A.,Tahir, I. 2015. Struktur Komunitas Ekosistem Mangrove di Kawasan Pesisir Sidangoli Kabupaten Halmahera Barat, Maluku Utara. Depik Jurnal, Vol 4, No 3 : 132-143.

Akbar, N., A. Baksir, Tahir I, Arafat D. 2016. Struktur komunitas mangrove di Pulau Mare, Kota Tidore Kepulauan, Provinsi Maluku Utara. Depik, 5(3): 133-142.

Akbar N, Marus I, Haji I, Abdullah S, Umalekhoa S, Ibrahim1 F.S., Ahmad M, Ibrahim A, Kahar A, dan Tahir I. 2017a. Struktur Komunitas Hutan Mangrove Di Teluk Dodinga, Kabupaten Halmahera Barat Provinsi Maluku Utara. Jurnal Enggano, 2 (1); 78-89

Akbar N, Haya N, Baksir A, Harahap Z.A, Tahir I, Ramili Y, Kotta R.2017b. Struktur komunitas dan pemetaan ekosistem mangrove di pesisir Pulau Maitara, Provinsi Maluku Utara, Indonesia. Depik jurnal, 6 (2): 167-181

Agustini N.T, Ta'alidin Z dan Purnama D. 2016. Struktur Komunitas Mangrove Di Desa Kahyapu Pulau Enggano. Jurnal Enggano, 1(1): 19-31

Aksornkoae S. 1993. Ecology and Management of Mangroves. Bangkok: IUCN

Alongi, D.M. 2002. Present state and future of the world's mangrove forests. Environmental Conservation 29 (3) : 331-349.

Ardiansyah, W.I, R. Pribadi \& S. Nirwan. 2012. Struktur dan komposisi vegetasi mangrove di kawasan pesisir Pulau Sebatik, Kabupaten Nunukan, Kalimantan Timur. Journal of Marine Research 1 (2): 203-215

Bengen, D.G. 2002. Ekosistem dan sumberdaya alam pesisir dan laut serta prinsip pengelolaannya. Pusat Kajian Sumberdaya Pesisir dan Lautan, Institut Pertanian Bogor, Bogor

Bengen, D. G., 2004. Pedoman Teknis Pengenalan dan Pengelolaan Ekosistem mangrove. Pusat Kajian Sumberdaya Pesisir Dan Lautan. IPB. Bogor.

Departemen Kelautan dan Perikanan (DKP). 2001. Pedoman Umum Pengelolaan Pulaupulau Kecil yang Berkelanjutan dan Berbasis Masyarakat. Ditjen Pesisir dan Pulaupulau Kecil, Jakarta. 21 hal. 
Dodd, R.S., Z. Afzal-Rafii, F. Fromard, F. Blasco. 1998. Evolutionary diversity among Atlantic coast mangroves. Acta Oecologica, 19: 323-330.

Duke, N.C., M C. Ball and J.C. Ellison. 1998. Factors influencing biodiversity and distributional gradients in mangroves. Global Ecology and Biogeography Letters 7 (1): 27-47.

Ernanto, R., F. Agustriani, R. Aryawati. 2010. Struktur komunitas gastropoda pada ekosistem mangrove di muara Sungai Batang Ogan Komering llir Sumatera Selatan. Maspari Journal, 01:73-78.

Fajar A, Oetama D dan Afu A. 2013. Studi Kesesuaian Jenis untuk Perencanaan Rehabilitasi Ekosistem Mangrovedi Desa Wawatu Kecamatan Moramo Utara Kabupaten Konawe Selatan. Jurnal Mina Laut Indonesia, 2 (12) ; 164-176

Gunarto. 2004. Konservasi mangrove sebagai pendukung sumber hayati perikanan pantai. Jurnal Litbang Pertanian, 23(1): 15-21.

Hakim, N. 2009. Penuntun Ringkas Dasar - Dasar Ilmu Tanah. Universitas Andalas: Padang.

Haji, I. 2014. Struktur Komunitas Ekosistem Mangrove di Desa Kaiyasa, Tidore Kepulauan. Skripsi. Fakultas Perikanan dan IImu Kelautan Universitas Khairun. Ternate.

Harahap S.A.B.N dan Mahudi M. $2014 . \quad$ Pemetaan Sebaran Hutan Mangrove dan Analisis Pasial Kesesuaian Lahan Budidaya Tambak di Pesisir Kecamatan Gending Kabupaten Probolinggo. Journal Of Environmental Engineering \& Sustainable Technology, 1 (2) : 75:82

Hardjowigeno S. 1987. IImu Tanah. Jakarta: Mediyatama Sarana Perkasa

Hardjowigeno, S. W. 2001. Kesesuaian lahan dan perencanaan tataguna tanah. Tesis. Institut Pertanian Bogor. Bogor.

Hogarth, P.J. 2007. The Biology of mangroves and seagrasses. Oxford University Press Inc., New York.

Indriani, D.P, H. Marisa \& Zakaria. 2009. Keanekaragaman spesies tumbuhan pada kawasan mangrove Nipah (Nypa fruticans Wurmb.) di Kec. Pulau Rimau Kab. Banyuasin Sumatera Selatan. Jurnal Penelitian Sains12 (3): 1-4

Kathiresan K, B.L. Bingham. 2001. Biology of mangroves and mangrove ecosystems. Advance Marine Biology, 40:81-251. 
Kjerfve, B., L.D. Lacerda. 1993. Mangroves of Brazil. In: Lacerda L.D. ed. Conservation and sustainable utilization of mangrove forests in Latin America and Africa Regions. Part I: Latin America. International Society for Mangrove Ecosystems and the International Tropical Timber Organization.

Kusmana, C dan Istomo. 1995. Ekologi Hutan. Laboratorium Kehutanan. Fakultas Kehutanan. Intitut Pertanian Bogor. Bogor.

Kusmana, C., S. Wilarso, I. Hilwan, P. Pamoengkas, C. Wibowo, T. Tiryana, A. Triswanto, Yunasfi, Hamzah, 2003. Teknik Rehabilitasi Mangrove. Fakultas Kehutanan IPB. Bogor. 177 Hal.

Kushartono E.W. 2009. Beberapa aspek Bio-Fisik Kimia Tanah di Daerah Mangrove Desa Pasar Banggi Kabupaten Rembang. Ilmu Kelautan, 14 (2) : 76-83

Kustanti, A. 2011. Manajemen Hutan Mangrove.IPB Press. Bogor. 348 hal.

Lembaga IImu Pengetahuan Indonesia. 2015. Survei Baseline Coremap CTI Kondisi Terumbu Karang dan Ekosistem Terkait di Ternate, Tidore dan Sekitarnya, Maluku Utara. Pusat Penelitian Oseanografi. Jakarta.

Mukhlisi, IGN. B,H, Hartuti P. 2013. Keanekaragaman Jenis dan Struktur Vegetasi Mangrove di Desa Sidodadi Kecamatan Padang Cermin Kabupaten Pesawaran, Provinsi Lampung. Prosiding Seminar Nasional Pengelolaan Sumberdaya Alam dan Lingkungan 2013

Muryani C. 2009. Analisis Faktor-Faktor Lingkungan Hutan Mangrove Pantai Pasuruan. Jurnal Geografi, 8 (1) :1113-1127

Noor, Y. R., M. Khazali, I. N. N. Suryadiputra. 2012. Panduan pengenalan mangrove di Indonesia. Cetakan ke-3. Bogor: Wetlands International Indonesia Programme.

Nybakken,W.J. 1988. Biologi Laut: Suatu Pendekatan Ekologis. PT. Gramedia, Jakarta.

Saru, A. 2009. Konstibusi Parameter Oseanografi Fisika Terhadap Distribusi Mangrove di Muara Sungai Pangkajene. J. Sains \& Teknologi, Vol 9 No.3 : 210- 217 
Setiawan H. 2013. Status Ekologi Hutan Mangrove Pada Berbagai Tingkat Ketebalan. Jurnal Penelitian Kehutanan Wallacea, 2 (2) : 104 120

Shan, L., Z. Ren-Chao, D. Sui-Sui, S. Su-Hua. 2008. Adaptation to salinity in mangroves: Implication on the evolution of salt-tolerance. Chinese Science Bulletin, 53(11): 1708-1715.

Supriharyono. 2002. Pelestarian dan pengelolaan sumber daya alam di wilayah pesisir tropis. PT. Gramedia Pustaka Utama, Jakarta.

Thampanya, U., J.E. Vermaat ., S. Sinsakul and N. Panapitukkul. 2006. Coastal erosion and mangrove progradation of Southern Thailand. Estuarine, Coastal and Shelf Science 68 (2006): 75-85

Triatmodjo, B. 1999. Tehnik pantai. Universitas Gajah Mada, Yogyakarta.

Tarigan, M. S. 2008. Sebaran Dan Luas Hutan Mangrove Di Wilayah Pesisir Teluk Pising Utara Pulau Kabaena Provinsi Sulawesi Tenggara. Makara, Sains, Vol 12, No. $2:-112$. 